\title{
Ocean observatory data are useful for regional habitat modeling of species with different vertical habitat preferences
}

\author{
John Manderson ${ }^{1, *}$, Laura Palamara $^{2}{ }$ Josh Kohut $^{2}$, Matthew J. Oliver ${ }^{3}$ \\ ${ }^{1}$ Ecosystems Processes Division, NEFSC/NMFS/NOAA, James J. Howard Marine Highlands, New Jersey 07732, USA \\ ${ }^{2}$ Institute of Marine and Coastal Science, Rutgers University, New Brunswick, New Jersey 08901, USA \\ ${ }^{3}$ College of Earth, Ocean and Environment, University of Delaware, Lewes, Delaware 19958, USA
}

\begin{abstract}
Ocean Observing Systems (OOS) now provide comprehensive descriptions of the physical forcing, circulation, primary productivity and water column properties that subsidize and structure habitats in the coastal ocean. We used generalized additive models (GAM) to evaluate the power of OOS remotely sensed ocean data along with in situ hydrographic and bottom data to explain distributions of 4 species important in the Mid-Atlantic Bight, USA, ecosystem that have different vertical habitat preferences. Our GAMs explained more abundance variation for pelagic species (longfin inshore squid and butterfish) than demersal species (spiny dogfish and summer flounder). Surface fronts and circulation patterns measured with OOS remote sensing as well as the rugosity and depth of the bottom were important for all species. In situ measurements of water column stability and structure were more useful for modeling pelagic species. Regardless of vertical habitat preference, the species were associated with vertical and horizontal current flows, and/or surface fronts, indicating that pelagic processes affecting movement costs, prey production and aggregation influenced distributions. Habitat-specific trends in abundance of 3 of the 4 species were well described by our OOSinformed GAMs based upon cross validation tests. Our analyses demonstrate that OOS are operationally useful for regional scale habitat modeling. Regional scale OOS-informed statistical habitat models could serve as bases for tactical ecosystem management and for the development of more sophisticated spatially explicit mechanistic models that couple ontogenic habitats and life history processes to simulate recruitment of organisms important to maintaining the resilience of coastal ecosystems.
\end{abstract}

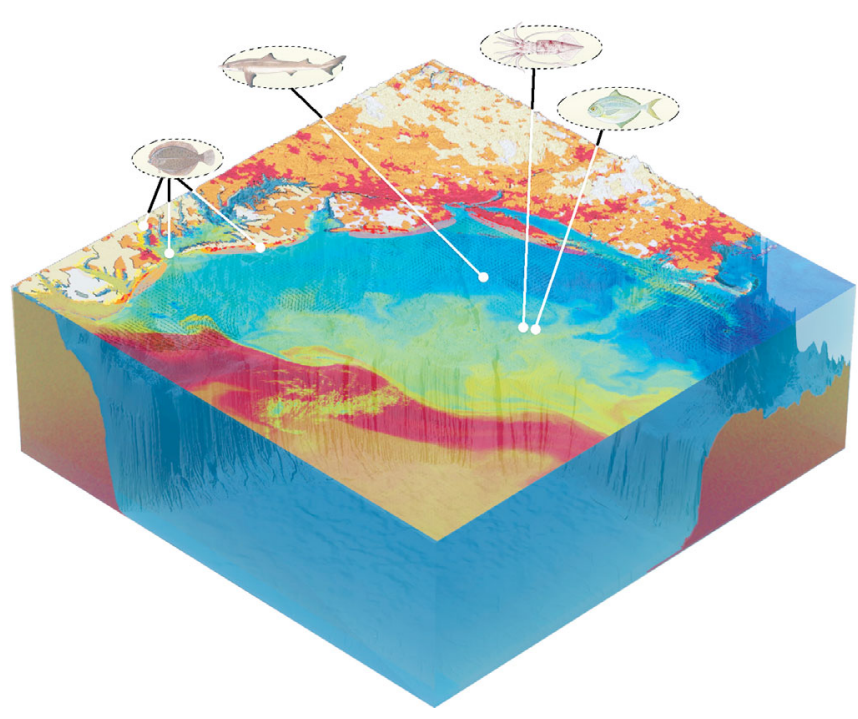

Data and models integrated in Ocean Observing Systems capture ocean dynamics at scales required for regional habitat modeling and management.

Image: Igor Heifetz

KEY WORDS: Ocean observing - Pelagic habitat · Remote sensing · Generalized Additive Modeling

Resale or republication not permitted without written consent of the publisher

\section{INTRODUCTION}

Species distributions reflect the habitat selection decisions individual animals make to maximize fitness under constraints imposed by their perceptual and movement capabilities. Variations in survival and reproduction are the consequences of con- 
strained habitat selection and the mechanistic underpinnings of spatial population dynamics. The diversity of habitats used by species, and effects of habitat variation on vital rates, including movements, determine the productivity, stability and resilience of regional populations (Secor et al. 2009, Tian et al. 2009, Kerr et al. 2010). Furthermore, the effects of habitat diversity and its loss on the resilience and stability of populations that serve as ecosystem keystones should be translated across a level of ecological organization to affect ecosystem productivity, resilience, and stability. Understanding the ways habitat effects on recruitment are translated into the emergent dynamics of regional populations important in maintaining the resilience of large marine ecosystems is crucial for the development of effective space-based ecosystem management, particularly in the face of rapid climate change (Mora et al. 2007, Hsieh et al. 2010). The development of statistical habitat models that are broad in scope and explicitly consider bottom features as well as the dynamic properties and processes of the water column (e.g. temperature, primary productivity, advection) known to regulate critical physiological, behavioral and demographic rates is a necessary first step toward this end.

Regional scale habitat models have been difficult to develop for coastal species, in part because data describing habitat variation at broad spatial but fine time scales have been unavailable. Ocean Observing Systems (OOS) now provide spatially and temporally comprehensive regional scale descriptions of pelagic features and processes required to understand the ways in which dynamic features of the ocean fluid affect the distribution and recruitment of fish living in it. Ocean Observing data include sea surface temperature and ocean color measured with satellite sensors, surface currents measured with networks of high-frequency (HF) radars deployed along the shore, and physical and optical properties measured by fleets of robots gliding beneath the ocean surface. The data describe the physical forcing, current flows, and sources and transport of detritus, primary and secondary productivity which structure, couple and fuel coastal ocean habitats and thus regulate the recruitment of animals using them. Remotely sensed data have been used to construct habitat models for open ocean pelagic predators, but are not commonly used for coastal species (Valavanis et al. 2008, Zainuddin et al. 2008, Becker et al. 2010, Mugo et al. 2010, Zydelis et al. 2011).

Presently, Ocean Observing data with the broadest spatial coverage are satellite measurements of ocean temperature and color, and HF radar measurements of surface currents. These data can be processed to describe upwelling and downwelling centers and the spatial dynamics of surface fronts where high primary productivity occurs or is concentrated. These products may therefore be most useful for identifying habitat associations of pelagic species. While surface data collected directly overhead of trawl samples may be less useful for describing habitats of demersal animals, particularly in deep water, the vital rates of demersal species are also regulated by surface processes, although effects may be downstream and delayed in time. Distributions of large demersal animals may be influenced to a greater degree by pelagic processes regulating movement costs and prey production, than by structural features of the bottom that may provide smaller and younger stages with predation refugia. Finally, surface features can serve as proxies for important subsurface properties and processes (Castelao et al. 2008).

We used generalized additive modeling to evaluate the power of Ocean Observing data, as well as in situ pelagic data and benthic data, to describe the distributions of 4 trophically important interacting species with different vertical habitat preferences in the Mid-Atlantic Bight US coastal ocean. We quantified the strength of species associations with mesoscale pelagic features described by OOS, as well as pelagic and benthic features measured with shipboard CTDs, acoustics and bottom grabs, emphasizing habitat characteristics likely to influence growth, dispersal, survival or reproduction. Finally, we discuss the potential value of current and future Ocean Observing assets and research for the development of regional scale habitat models that could serve as fundamental tools for understanding the role of marine habitat dynamics in ecosystem dynamics and the development of more effective space- and timebased ecosystem management strategies.

\section{MATERIALS AND METHODS}

\section{Study area}

Our study area was the Mid-Atlantic Bight (MAB), USA, where the dynamics of the coastal ocean are continuously monitored at broad spatial scales but fine time scales by the Mid-Atlantic Regional Association Coastal Ocean Observing System (MARACOOS: http://maracoos.org; Fig. 1). The oceanography of the MAB is described in detail elsewhere (Beardsley \& Boicourt 1981, Epifanio \& Garvine 2001, Lentz 2008). Briefly, the broad, gently sloping continental shelf in 


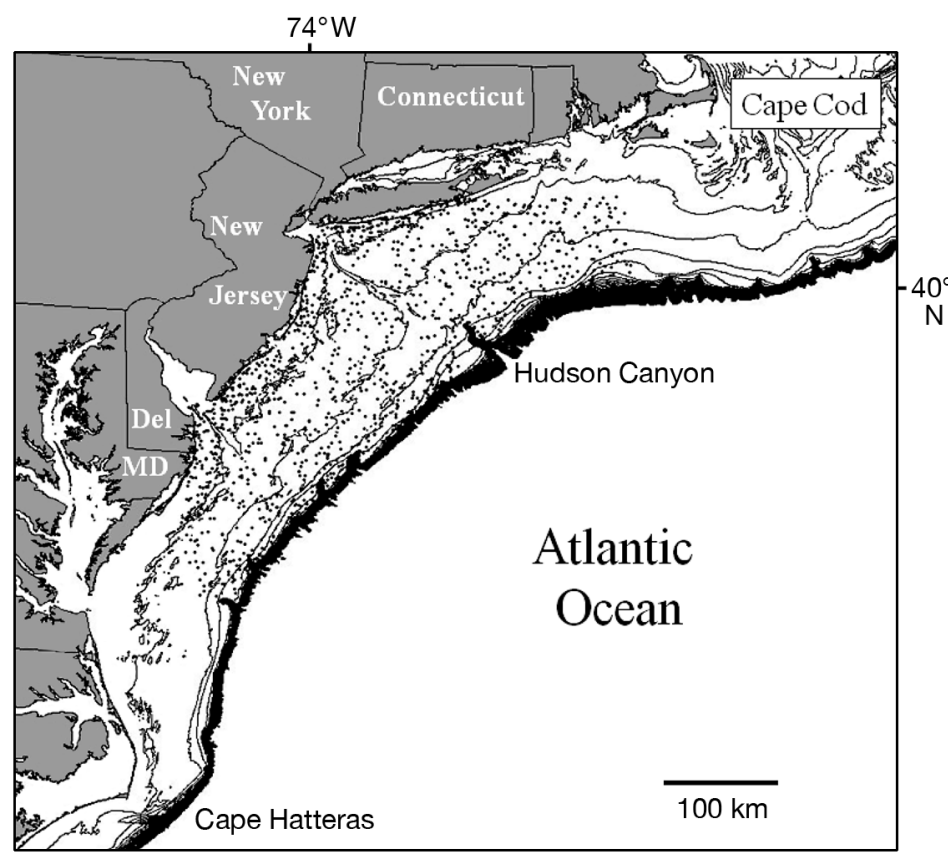

Fig. 1. Locations on the Mid-Atlantic Bight continental shelf, USA, of stations sampled during North East Fisheries Science Center fisheryindependent bottom trawl surveys and considered in our analysis of longfin inshore squid, butterfish, spiny dogfish and summer flounder habitat

the MAB is incised by canyons and drowned river valleys that serve as important cross shelf transport pathways. Mean current flow is southwestward and driven by cold buoyant water derived from the northeast. Biological productivity is strongly seasonal. However, air and ocean temperatures, stratification, and wind and buoyancy forcing are extremely variable and superimpose complex, ecologically important variation on mean patterns. Mean southwestward current flows can be intensified by southward, downwelling favorable winds and estuarine discharge, or steered offshore by northward, upwelling favorable winds associated with approaching atmospheric fronts and summer sea breezes. Wind forcing results in sea surface set up and set down along the coast that produces cross-shelf, subsurface counter flows that are strongest along drowned river valleys. During the summer, areas of high primary productivity occur in estuaries and nearshore upwelling centers. During the spring, meanders in the shelf slope front produce upwelling of deep nutrient-rich oceanic waters that, with increasing solar radiation, promote an early bloom in the shelf slope sea (Marra et al. 1990, Ryan et al. 1999). Spring blooms fueled by nutrients supplied by winter water column overturning occur with the onset of stratification closer to shore, while blooms also occur on the shelf when stratifica- tion breaks down in the autumn. Organisms occupying the MAB exhibit complex seasonal cycles of reproduction and habitat use in response to the complex seasonal dynamics of ocean climate, circulation and primary productivity.

\section{Species abundance data}

We selected longfin inshore squid Loligo pealeii, butterfish Peprilus triacanthus, spiny dogfish Squalus acanthias and summer flounder Paralichthys dentatus for analysis because they exhibit differences in vertical habitat preference, are abundant in fishery-independent bottom trawl surveys and are trophically important interacting species in the MAB (Link et al. 2008). Butterfish and longfin squid are small pelagic species important in the transfer of energy from lower trophic levels to apex predators (Link et al. 2008). Both species reach maturity at a year or less of age and have very high reproductive rates (Hatfield \& Cadrin 2002, Collette \& Klein MacPhee 2002). Butterfish feed primarily upon zooplankton. Squid feed on small pelagic animals including butterfish.

Spiny dogfish and summer flounder feed upon squid and butterfish but generally spend more time deeper in the water column (Packer \& Hoff 1999, Moustahfid et al. 2010, Staudinger 2006, Stehlik 2007). Spiny dogfish are not as surface oriented as squid and butterfish but still spend considerable amounts of time in the water column. They exert strong top down effects on the MAB food web. Summer flounder are subtropical flatfish more strongly associated with the seabed in the ocean and estuaries.

All 4 species migrate between lower latitude and/or offshore overwintering habitats to higher latitude, inshore habitats where they spend the summer. Longfin inshore squid, butterfish and summer flounder are abundant in the MAB throughout the year while spiny dogfish are more abundant in cooler waters to the northeast during the summer (Stehlik 2007).

We used collections of the 4 species made by National Marine Fisheries Service, Northeast Fisheries Science Center's (NMFS-NEFSC) autumn, winter, and spring fisheries independent bottom trawl survey (Fig. 1; www.nefsc.noaa.gov/epd/ocean/Main Page/ioos.html) in our statistical habitat modeling. Azarovitz (1981) described the design of the stratified random survey in detail. Winter surveys occurred in February, spring surveys from March to early May, 
and autumn surveys in September and October. Survey tows were made with a \#36 Yankee trawl with a $10.4 \mathrm{~m}$ wide $\times 3.2 \mathrm{~m}$ high opening and rollers $(12.7 \mathrm{~cm}$ stretched mesh [SM] opening, $11.4 \mathrm{~cm}$ SM cod end, $1.25 \mathrm{~cm}$ SM lining in the cod end and upper belly). The net was towed over the bottom at $\sim 3.5$ knots for $30 \mathrm{~min}$. Distances the net was towed on the bottom averaged $3.5 \mathrm{~km}$ (95\% confidence limits 3.2 to $3.7 \mathrm{~km}$ ). Tows were made throughout the $24 \mathrm{~h}$ day. Consecutive samples were collected approximately every $2 \mathrm{~h}$ (50th, 5th, and 95th quantiles: 2.07, $1.38,3.53 \mathrm{~h}$ respectively) and $19 \mathrm{~km}$ apart (50th, 5th, and 95th quantiles: 19.02, 4.80, $41.88 \mathrm{~km}$ respectively) on each survey. Examination of available length and age frequencies confirmed that large age 1+ juveniles and adults dominated collections because the trawl mesh was relatively coarse and shallow coastal and estuarine nursery habitats were not sampled.
We selected the analysis domain for this study based upon the availability of remotely sensed data from the OOS. Bottom trawl samples collected from February 2003 through October 2007 between latitudes $37.14^{\circ}$ and $40.85^{\circ} \mathrm{N}$ and longitudes $70.83^{\circ}$ and $75.16^{\circ} \mathrm{W}$ fit within the domain (Fig. 1). An average of 101 stations was sampled during spring and autumn. An average of 70 stations was sampled during the winter.

\section{Habitat data}

For bottom data, we computed topographic characteristics of the bottom from the 3-arc-second NGDC Coastal Relief Model (www.ngdc.noaa.gov/mgg/ coastal/coastal.html; cell size $=93 \mathrm{~m}$; Table 1). We used circular moving window analysis in GRASS GIS to calculate median and standard deviations of bot-

Table 1. Data sources and potential ecological effects of environmental variables considered in generalized additive model (GAM) habitat models for longfin inshore squid, butterfish, spiny dogfish and summer flounder. Squid and butterfish were considered prey in auxiliary models for spiny dogfish and summer flounder predators. na = not applicable, ": same data as given in the line above

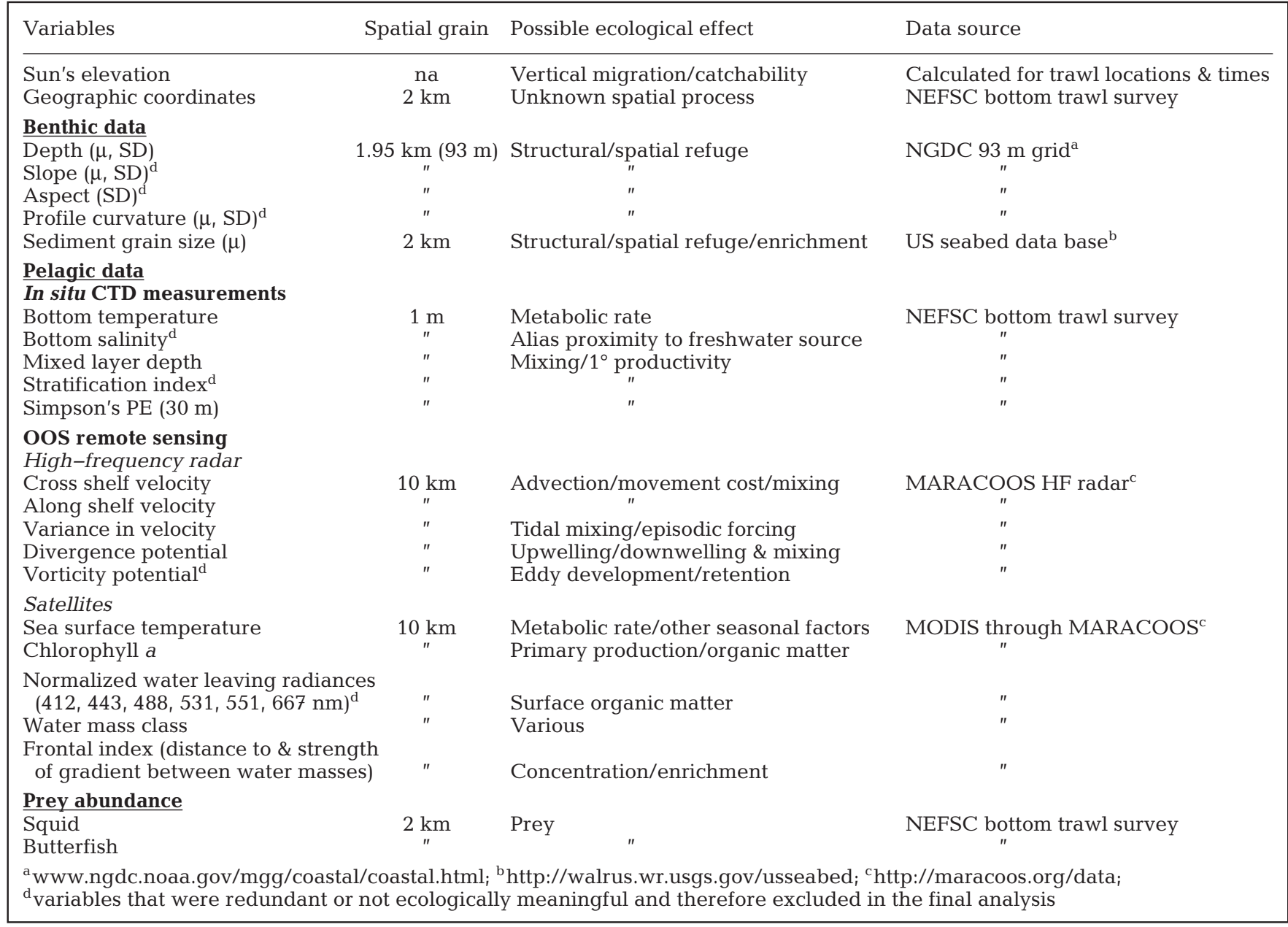


tom depth, aspect, slope, and curvature from the relief model (e.g. see Fig. 3; Neteler \& Mitasova 2008). The window diameter was $2 \mathrm{~km}$. Profile and tangential curvature measured the concavity (negative values indicate valleys) and convexity of the bottom (positive values indicate ridges) parallel and tangential to major axes of the bottom slope. Sediment grain sizes were selected from a map interpolated from the usSEABED data base (Reid et al. 2005). The sediment map had a spatial resolution of $2 \mathrm{~km}$ and was constructed using sample bias correction, maximum a posteriori resampling, and a spline-in-tension algorithm (Goff et al. 2006, 2008).

For pelagic data, we used conductivity, temperature and depth (CTD) profiles collected during each NEFSC trawl survey to describe bottom temperature and salinity, water column structure and stability (Table 1; www.nefsc.noaa.gov/epd/ocean/Main Page/ioos.html). We considered the 'mixed layer' depth at which density was $0.125 \mathrm{~kg} \mathrm{~m}^{-3}$ higher than the surface (Levitus 1982), a stratification index calculated as the difference in seawater density between the surface and $50 \mathrm{~m}$, and Simpson's potential energy anomaly ( $\mathrm{PE}$; Simpson 1981, Simpson \& Bowers 1981). We calculated Simpson's PE within the upper $30 \mathrm{~m}$ of the water column because the stability index calculated for the entire water column was correlated with bottom depth.

A network of HF radar provided remotely sensed measurements of surface currents (Table 1 ; http:// maracoos.org; frequency $=5 \mathrm{MHz}_{\text {; }}$ Barrick et. al. 1977). Radial current vectors from the network were combined to produce hourly surface current maps (resolution $=6 \mathrm{~km}$ ). We de-tided the raw time series at each HF radar grid point using a least-squares fit of the 5 strongest principal body tide constituents (M2, $\mathrm{S} 2, \mathrm{~N} 2, \mathrm{~K} 1$, and O1). These data were then low pass filtered with a cutoff period of $30 \mathrm{~h}$. We only used data for grid points with signal returns of $>25 \% \mathrm{yr}^{-1}$. We calculated $8 \mathrm{~d}$ average cross-shore and along-shore velocity, variance in velocity, divergence (vertical velocity) and vorticity within $10 \mathrm{~km}$ of each trawl. Divergence and vorticity were calculated using finite difference. Divergence was calculated as the vertical current velocity in $\mathrm{m} \mathrm{d}^{-1}$ at a depth of $1 \mathrm{~m}$. Vorticity was normalized by the local Coriolis parameter. We also calculated indices describing seasonal trends in divergence and vorticity. Instantaneous divergence values were assigned a new value of -1 if values were $<-0.1 \mathrm{~m} \mathrm{~d}^{-1}, 0$, if between -0.1 and $+0.1 \mathrm{~m} \mathrm{~d}^{-1}$, or +1 if values were $>+0.1 \mathrm{~m} \mathrm{~d}^{-1}$. These new values were averaged for each grid point to produce a mapped index of upwelling and downwelling potential for each sea- son and year (e.g. see Fig. 3). Seasonal trends in vorticity were calculated similarly using threshold values of \pm 0.02 . Values for the trawl samples were extracted from the grids.

Satellite remote sensing provided surface temperature, chlorophyll a ( $\mathrm{chl}$ a), raw light absorption and backscatter within $10 \mathrm{~km}$ of each trawl tow (Table 1). Moderate Resolution Imaging Spectrometer (http://oceancolor.gsfc.nasa.gov) data were binned to $1 \mathrm{~km}$ resolution using standard data quality flags. We considered measurements of sea surface temperature, chlorophyll ( $\mathrm{mg} \mathrm{m}^{-3}$; e.g. see Fig. 3), and normalized water-leaving radiance $\left(\mathrm{W} \mathrm{m}^{-2} \mathrm{st}^{-1} \mathrm{\mu m}^{-1}\right)$ at $412,443,488,531,551$, and $667 \mathrm{~nm}$ in our analysis.

Ensemble clustering was applied to satellite sea surface temperature and normalized water-leaving radiance at 443 and $555 \mathrm{~nm}$ to classify water masses using the methods of Oliver et al. (2004) and Oliver \& Irwin (2008). Clustering identified 27 water masses within the study domain. We made time series maps of the strengths of gradients along frontal boundaries between these water masses (e.g. see Fig. 3) and used them to compute distance $\left(\mathrm{d}_{\mathrm{km}}\right)$ to, and gradient strength $(G)$ of the nearest front for each trawl sample. We then calculated a frontal index (FI) for each station using the equation:

$$
\mathrm{FI}=\ln \left(G / \mathrm{d}_{\mathrm{km}}+1\right)
$$

Values for the frontal index were therefore higher for samples nearer to stronger fronts.

Many of 27 water masses identified with ensemble clustering contained 5 or fewer trawl samples. Thus, before final assignment of the samples to water masses, we used k-means clustering of the original satellite data to reduce the number of water masses from 27 to 8 . Following this clustering, each of the 8 water masses contained at least 20 bottom trawl samples.

\section{Analysis}

GAMs

We developed our statistical habitat models for large juvenile and adult stage squid, butterfish, dogfish and summer flounder, using generalized additive models (GAM) implemented with the mgcv package in R software (Wood 2006). GAM is a nonparametric multiple regression technique that does not require shapes of abundance responses to habitat variables to be specified a priori. It has been used to statistically model ecological relationships, including habitat associations, and performs well in comparison 
with other methods (Pearce \& Ferrier 2000, Ciannelli et al. 2007, Ficetola \& Denoël 2009). Like all regressions, GAMs constructed with collinear independent variables perform poorly. We therefore eliminated intercorrelated variables prior to modeling, retaining those most likely to affect important physiological or behavioral processes (Table 1).

We standardized species abundances by trawl tow distances and found they were best modeled using an over-dispersed Poisson distribution. Using this distribution required that we round abundances to the nearest integer. Abundance in bottom trawls can vary with time of sampling if animals exhibit diel behavioral cycles, especially vertical migration (e.g. Brodziak \& Hendrickson 1999). As a result, we considered solar elevation at trawl locations and times as a covariate in GAMs.

To construct GAMs we used a backward stepwise procedure to select habitat covariates that minimized the generalized cross validation statistic (GCV, Wood 2006). We set gamma to 1.4 , which increased the penalty for models of greater complexity (higher degrees of freedom). We set the maximum basis dimension of smoothers $(\mathrm{k})$ to 4 , which limited the complexity of the response functions to the nonparametric equivalent of a 3rd degree polynomial, and thus a Gaussian-like response. These conservative settings reduced our chances of over fitting the models. We used smoothing splines to model single term covariates which we eliminated beginning with those with the highest $\mathrm{p}$-values in approximate F-tests. We retained only those habitat covariates producing lower GCV and significant reduction in residual deviance at the $\mathrm{p}<0.05$ level in analysis of deviance of nested models, which were also likely to affect the animals through mechanisms we understood. We examined residual and convergence diagnostics throughout the modeling process.

Following the construction of single term models, we evaluated first order interactions among retained covariates using tensor product smooths (Wood 2006). We found that nearly all significant first order interactions included sea surface temperature (SST), which was seasonally discontinuous between the autumn (warm SST $>17^{\circ} \mathrm{C}$ ) and the winter and spring $\left(\mathrm{SST}<15^{\circ} \mathrm{C}\right.$ ) surveys. As a result, we constructed a factor for season based upon SSTs (warm [autumn] vs. cold [winter \& spring]), and determined whether abundance responses to the habitat covariates were seasonally dependent. Seasonally dependent habitat responses were retained if they produced lower GCVs and residual deviance in analysis of nested models $(p<0.05)$. Once we formulated these final models we added spatial co-variates (latitude and longitude) to identify residual spatial variation in abundance that was not well described by retained habitat covariates. We also included logtransformed abundances of squid and butterfish as covariates in spiny dogfish and summer flounder GAMs to evaluate the effects of prey distributions on distributions of the predators.

We used deviance partitioning ( variance partitioning) to quantify the independent and joint effects on species distributions of habitat covariates included in the final models which we organized into 3 sets: mesoscale pelagic features described by OOS; pelagic features based on CTD casts and benthic features measured with acoustics or bottom grabs (Borcard \& Legendre 1994, Cushman \& McGarigal 2002). We used partial GAM regression and nested analysis of deviance to compute independent and intercorrelated effects of the 3 variable sets on abundance patterns.

Model evaluation

We evaluated our GAMs using a cross validation out-of-sample prediction procedure that bootstrapped Spearman correlations between standardized abundance and abundance predicted with habitat covariates in the final GAMs. In each of 1000 iterations, $10 \%$ of the observations were randomly selected using a uniform distribution and set aside as test data. The remaining training observations were used to fit abundance to the habitat covariates included in the final GAMs. At each iteration the trained GAM was used to predict the relationship between habitat covariates and abundance in the test data. Predicted abundances were then compared with measured abundances in the test data using Spearman's rho. We calculated 50th, 5th, and 95th quantiles to estimate median and $95 \%$ confidence intervals for the bootstrapped rhos.

\section{Demonstration projection of a habitat model}

We modified the final summer flounder habitat GAM to accept available raster data layers for the autumn of 2008, and qualitatively compared this model projection with animal collections made from September 3 through November 13 during the NEFSC bottom trawl survey. We selected autumn 2008 for the demonstration because it was nearest in time to surveys used to train the habitat model (2003 to 2007) and because 2008 was the first year the 
MARACOOS HF radar network continuously monitored surface currents throughout the MAB coastal ocean from Cape Hatteras to Cape Cod. The October 1, 2008 model projection used $8 \mathrm{~d}$ averaged satellite data and a $32 \mathrm{~d}$ rolling 'seasonal' trend in divergence (see Fig. 3). In the demonstration, we eliminated subsurface measures of water column properties because estimates are not currently accessible in near real time using operational remote sensing assets or models.

\section{RESULTS}

The explanatory power of GAMs made for the 2 pelagic species, squid and butterfish, was higher than for models made for spiny dogfish and summer flounder (Table 2, Fig. 2). Our models accounted for $73 \%$ of abundance variation for pelagic species, and $\sim 50 \%$ of the variation for the demersal species. Models for pelagic species incorporated more pelagic habitat covariates measured with in situ CTD sampling. Models for demersal species did not, however, accept more of the benthic habitat covariates measured at relatively coarse spatial grains. Benthic covariates did not have greater explanatory power in demersal species models. Responses of the animals to many of the habitat covariates were seasonally dependent, and habitat distributions were better described during the winter and early spring than during the autumn when surface waters were stratified and animals were migrating, or soon to migrate, to overwintering habitats.

Bottom depth and variations in bottom depth (SD depth) met selection criteria in GAMs for all 4 species, and associations with seabed characteristics were seasonally dependent in every case (Table 2; see the Supplement at www.int-res.com/articles/ suppl/m438p001_supp.pdf). During winter and early spring when temperatures were cold, the animals were abundant in deeper, offshore waters. Squid, butterfish, and summer flounder were most abundant over bottoms with depths ranging from 50 to $150 \mathrm{~m}$. Spiny dogfish were more abundant in shallower habitats $(<75 \mathrm{~m})$. Deep overwintering habitats for squid and summer flounder were topographically complex (high STD depth) and located in the outer Hudson shelf valley and along the edge of the continental shelf. During winter, dogfish were also abundant over complex bottoms. Butterfish were more common over smooth bottoms. During autumn, abundance varied with depth only for butterfish which were rare over bottoms deeper than $150 \mathrm{~m}$. Butterfish preferred complex bottoms in the nearshore during the autumn.

Bottom water temperature met selection criteria in GAMs for all 4 species (Table 2, see Supplement). Temperature responses of longfin squid, butterfish, and summer flounder were not seasonally dependent. All 3 species were rare where bottom temperatures were $<6.5^{\circ} \mathrm{C}$. Summer flounder, butterfish and squid were also uncommon on the continental shelf where bottom temperatures were warmer than $12.5^{\circ} \mathrm{C}, 16^{\circ} \mathrm{C}$, and $20^{\circ} \mathrm{C}$, respectively. In contrast, the temperature response of spiny dogfish was seasonally dependent. The sharks overwintered where bottom water temperatures were warmer than $7^{\circ} \mathrm{C}$. During the autumn, dogfish preferred cool temperatures measured in the northern part of the study area.

Water column stability measured in situ and indexed as Simpson's PE anomaly for the upper $30 \mathrm{~m}$ of the water column met model selection criteria for squid, butterfish and summer flounder, while the abundance of butterfish also varied with mixed layer depth (Table 2, see Supplement). Summer flounder were consistently more abundant where the water column was stable in the vicinity of estuarine plumes during the autumn and the outer continental shelf during the winter and spring. Both pelagic species were more abundant where the water column was unstable during the autumn. In the winter, butterfish were more abundant where the water column was stable and the mixed layer was deep near the shelf slope front (see below, this section). Water column stability and stratification measured in situ varied negatively with surface current velocities and positively with current variances measured with HF radar. This produced relatively high, intercorrelated habitat effects in GAMs for the pelagic species (Table 2, Fig. 2).

Pelagic habitat characteristics measured remotely with satellites and HF radar did not have consistently greater explanatory power in models for the pelagic species than the demersal species (Table 2, Fig. 2). At least one remotely sensed pelagic characteristic met selection criterion for each species and the independent effects of remotely sensed variables were actually slightly higher in the GAM for summer flounder than for the pelagic species (Table 2, Fig. 2, see Supplement).

Summer flounder, butterfish and squid were most abundant in areas where the index of surface current divergence, and thus upwelling potential, was high (Table 2, Fig. 3, see Supplement). This response was seasonally dependent for the 2 pelagic species, but not for summer flounder. 
Table 2. Analysis of deviance from generalized additive habitat modeling of longfin inshore squid, butterfish, spiny dogfish and summer flounder abundances in the Mid-Atlantic Bight coastal ocean (see also Fig. 2). Partial deviance is the additional deviance 'explained' by each variable after effects of other variables were removed. Null model is an approximation of the total deviance ( variance) in abundance data. \% of Null expresses the deviance and partial deviance as a percentage of the Null Model for each species. The decrease in the generalized cross validation statistic $(\triangle \mathrm{GCV})$ is indicated in the last column. Only variables that resulted in an increase in GCV when they were removed in backward selection were included in the final models and reported here

\begin{tabular}{|c|c|c|c|c|c|c|}
\hline \multirow{2}{*}{$\begin{array}{l}\text { Species } \\
\text { Longfin inshore squid }\end{array}$} & \multirow{2}{*}{$\begin{array}{l}\text { Habitat variable } \\
\text { Bottom temperatures }\end{array}$} & \multicolumn{2}{|c|}{ Deviance \% of Null } & \multicolumn{2}{|c|}{ Partial deviance \% of Null } & \multirow{2}{*}{$\begin{array}{r}\Delta \mathrm{GCV} \\
150.7\end{array}$} \\
\hline & & 260027.0 & 40.4 & 50878.0 & 7.9 & \\
\hline & Cross shelf velocity ${ }^{\mathrm{a}}$ & 24295.0 & 3.8 & 24173.0 & 3.8 & 62.2 \\
\hline & Watermass & 135449.0 & 21.0 & 22388.0 & 3.5 & 59.6 \\
\hline & Bottom depth ${ }^{\mathrm{a}}$ & 214195.0 & 33.2 & 17068.0 & 2.6 & 41.7 \\
\hline & STD bottom depth ${ }^{\mathrm{a}}$ & 156599.0 & 24.3 & 14255.0 & 2.2 & 37.6 \\
\hline & Sun's elevation ${ }^{\mathrm{a}}$ & 59145.0 & 9.2 & 13172.0 & 2.0 & 22.5 \\
\hline & Simpson's PE $(30 \mathrm{~m})^{\mathrm{a}}$ & 77978.0 & 12.1 & 10939.0 & 1.7 & 21.1 \\
\hline & Divergence index ${ }^{\mathrm{a}}$ & 24633.0 & 3.8 & 8038.2 & 1.2 & 15.4 \\
\hline & Frontal index ${ }^{\mathrm{a}}$ & 5115.9 & 0.8 & 6971.1 & 1.1 & 6.3 \\
\hline & Cross shelf variance (vel.) & 8614.1 & 1.3 & 4051.5 & 0.6 & 10.0 \\
\hline & Benthic habitat data & & & 37586.0 & 5.8 & \\
\hline & Pelagic habitat data (in situ) & & & 70533.0 & 10.9 & \\
\hline & Pelagic habitat data (remote) & & & 80824.0 & 12.5 & \\
\hline & Final model & 474644.5 & 73.7 & & & \\
\hline & Residual & 169746.3 & 26.3 & & & \\
\hline & Null model & 644390.8 & & & & \\
\hline & Spatial coordinates & 206838.0 & 32.1 & 66810.0 & 10.4 & 171.3 \\
\hline \multirow[t]{17}{*}{ Butterfish } & Bottom depth ${ }^{a}$ & 40207.0 & 23.6 & 8846.3 & 5.2 & 21.3 \\
\hline & Bottom temperature & 27987.0 & 16.4 & 8152.1 & 4.8 & 23.7 \\
\hline & Cross shelf velocity $^{\mathrm{a}}$ & 6343.5 & 3.7 & 8090.8 & 4.7 & 22.5 \\
\hline & Sun's elevation & 4759.3 & 2.8 & 7229.3 & 4.2 & 16.5 \\
\hline & STD bottom depth ${ }^{\mathrm{a}}$ & 18282.0 & 10.7 & 6948.0 & 4.1 & 18.5 \\
\hline & Divergence index ${ }^{a}$ & 5482.3 & 3.2 & 6903.8 & 4.0 & 15.2 \\
\hline & Mixed layer depth ${ }^{\mathrm{a}}$ & 873.4 & 0.5 & 5490.5 & 3.2 & 12.1 \\
\hline & Frontal index ${ }^{\mathrm{a}}$ & 23422.0 & 13.7 & 4922.1 & 2.9 & 11.8 \\
\hline & Simpson's PE $(30 \mathrm{~m})^{\mathrm{a}}$ & 11882.0 & 7.0 & 4288.6 & 2.5 & 9.6 \\
\hline & Cross shelf variance (vel.) & 101.1 & 0.1 & 1335.1 & 0.8 & 3.2 \\
\hline & Benthic habitat data & & & 21218.0 & 12.4 & \\
\hline & Pelagic habitat data (in situ) & & & 23151.0 & 13.6 & \\
\hline & Pelagic habitat data (remote) & & & 21269.0 & 12.5 & \\
\hline & Final model & 124984.6 & 73.2 & & & \\
\hline & Residual & 45673.4 & 26.8 & & & \\
\hline & Null model & 170658.0 & & & & \\
\hline & Spatial coordinates & 63635.5 & 37.3 & 17360.0 & 10.2 & 44.6 \\
\hline \multirow[t]{13}{*}{ Spiny dogfish } & Bottom temperature ${ }^{a}$ & 42380.0 & 40.0 & 22554.0 & 21.3 & 35.7 \\
\hline & Along shelf variance (vel.) ${ }^{\mathrm{a}}$ & 21770.0 & 20.6 & 3938.9 & 3.7 & 5.3 \\
\hline & Bottom depth ${ }^{\mathrm{a}}$ & 7090.1 & 6.7 & 3409.8 & 3.2 & 4.5 \\
\hline & STD bottom depth ${ }^{\mathrm{a}}$ & 4008.4 & 3.8 & 2414.9 & 2.3 & 3.1 \\
\hline & Sun's elevation & 3628.1 & 3.4 & 844.0 & 0.8 & 0.8 \\
\hline & Benthic habitat data & & & 5913.8 & 5.6 & \\
\hline & Pelagic habitat data (in situ) & & & 22554.0 & 21.3 & \\
\hline & Pelagic habitat data (remote) & & & 3938.9 & 3.7 & \\
\hline & Final model & 53152.6 & 50.2 & & & \\
\hline & Residual & 52670.0 & 49.8 & & & \\
\hline & Null model & 105822.6 & & & & \\
\hline & Prey [log(squid)] & 29544.0 & 27.9 & 2434.2 & 2.3 & 3.1 \\
\hline & Spatial coordinates & 40954.6 & 38.7 & 15075.0 & 14.2 & 20.1 \\
\hline
\end{tabular}


Table 2 (continued)

\begin{tabular}{|c|c|c|c|c|c|c|}
\hline Species & Habitat variable & \multicolumn{2}{|c|}{ Deviance \% of Null } & Partial devia & $\%$ of Null & $\triangle \mathrm{GCV}$ \\
\hline \multirow[t]{16}{*}{ Summer flounder } & Chlorophyll $a^{\mathrm{a}}$ & 2556.9 & & & & \\
\hline & Bottom depth ${ }^{\mathrm{a}}$ & 2955.5 & & & & \\
\hline & Bottom temperature & 1322.6 & & & & \\
\hline & Frontal index ${ }^{a}$ & 290.3 & & & & \\
\hline & STD bottom depth & 214.4 & & & & \\
\hline & Divergence index & 161.9 & & & & \\
\hline & Benthic habitat data & & & 1288.8 & 12.9 & \\
\hline & Pelagic habitat data (in situ) & & & 676.7 & 6.8 & \\
\hline & Pelagic habitat data (remote) & & & 1302.3 & 13.1 & \\
\hline & Final model & 5017.8 & 50.4 & & & \\
\hline & Residual & 4934.5 & 49.6 & & & \\
\hline & Null model & 9952.3 & & & & \\
\hline & Spatial coordinates & 2462.8 & 24.7 & 652.3 & 6.6 & 1.2 \\
\hline & Prey [log(squid)] & 3379.7 & 34.0 & 1053.3 & 10.6 & 2.7 \\
\hline & Prey [log(butterfish)] & 3561.7 & 35.8 & 795.7 & 8.0 & 2.0 \\
\hline & Both prey & & & 1323.5 & 13.3 & 3.4 \\
\hline
\end{tabular}

During autumn, summer flounder was associated with nearshore areas where chl a concentrations were relatively high (Fig. 3, see Supplement). These areas were in close proximity to estuarine plumes. The animals were rarely collected where surface chl $a$ was highest during winter and spring.

Squid, butterfish and summer flounder abundance varied with proximity to, and the strength of, surface fronts identified with satellites (Table 2, Fig. 3, see Supplement). Associations with fronts were strong during cold seasons but weak or absent during the autumn when the water column was warm and stratified. The pelagic species were associated with fronts on the outer continental shelf during the winter and spring. Summer flounder were rarely collected close to these strong fronts.

Although proximity to fronts between water masses was important in 3 of 4 habitat models, water mass type only met model selection criterion for longfin squid (see Supplement). Squid were slightly more abundant in water masses of moderate temperature, salinity, and primary productivity that occurred over intermediate bottom depths.

Squid and butterfish appeared to respond to cross shelf surface current velocities (see Supplement). During autumn, the animals were common where strong surface currents were directed offshore. They were abundant during winter and spring where high surface current velocities were directed inshore. The pelagic species also preferred areas where surface current velocities were relatively consistent (low variance in velocity). The response of spiny dogfish to variance in velocity was similar.
During the winter and spring, summer flounder and spiny dogfish were associated with the pelagic species they prey upon on the outer continental shelf (Table 2, Fig. 2, see Supplement). Both predators were abundant where squid were abundant, while summer flounder were also associated with butterfish.

Maps of residual spatial variation made by adding spatial covariates indicated that abundances of squid and butterfish were lower in the nearshore off Long Island, New York, than predicted based upon the habitat covariates included in the final models (Table 2, see Supplement). Squid were more abundant during the winter offshore south of Hudson shelf valley, while butterfish abundance was higher than predicted in the autumn just southeast of the Sandy Hook peninsula where the Hudson-Raritan estuary discharges into the coastal ocean. Dogfish abundance was overestimated at the mouth of the Hudson-Raritan estuary and along the continental shelf break based upon retained habitat covariates. Finally, there was a cross shelf gradient in errors in the GAM for summer flounder, which were less abundant than predicted in the nearshore continental shelf, but more abundant offshore north of the Hudson Shelf Valley.

The out-of-sample prediction test indicated that habitat-specific trends in abundances of longfin inshore squid, spiny dogfish and summer flounder were well described by our GAMs (Fig. 4). Bootstrapped rank correlations between predicted and actual catches were $>0.7$ and confidence intervals were relatively narrow for squid and spiny dogfish. For the butterfish model, correlations between pre- 


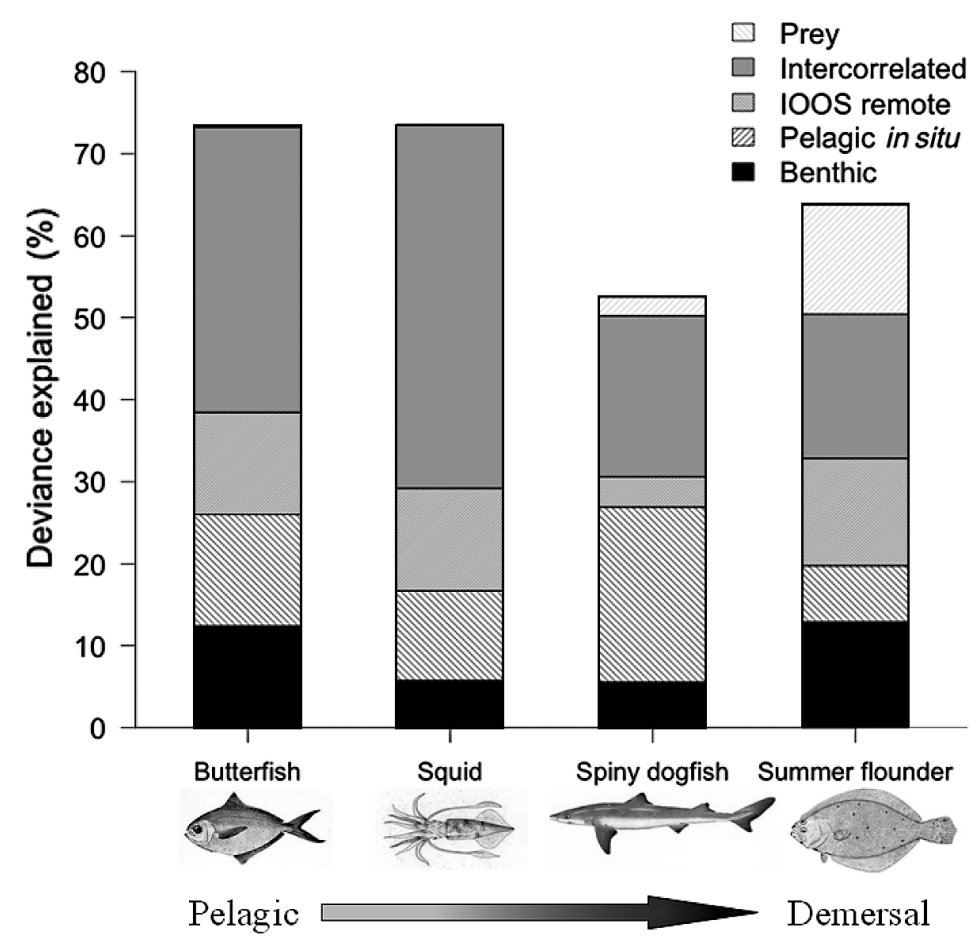

Fig. 2. Partial deviance ( variance) components calculated from generalized additive model (GAM) habitat modeling for 4 species with different vertical habitat preferences in the coastal ocean (see Table 2 and the Supplement available at www.int-res.com/articles/suppl/ m438p001_supp.pdf). Less of the abundance variation was 'explained' for demersal than for pelagic species, whose distributions appeared to be more directly affected by water column stability and mixed layer depth measured in situ. These variables were correlated with HF radar surface current measurements. Percentages depicted for Prey, IOOS remote, Pelagic in situ and Benthic habitat feature groups are partial components after intercorrelated effects (also shown) were removed. Spatial covariates were not included in this analysis

dicted and actual abundances were weaker and confidence intervals were wide.

Actual catches of summer flounder during autumn 2008 generally matched the demonstration projection of the statistical habitat model we modified to accept OOS ocean data for October 1. Catches were relatively high offshore south of Martha's Vineyard, and in shallower water from the mouth of Long Island Sound west to the mouth of the Hudson-Raritan estuary to central New Jersey.

\section{DISCUSSION}

Broad scale dynamic habitat models for species contributing resilience to large marine ecosystems could be useful for space- and time-based ecosystem management. However, operational habitat models require sustained collection of high resolution data describing pelagic and benthic processes affecting the physiologies, behaviors and ecologies of important species at the scale of large marine ecosystems. These kinds of data are much too expensive and time consuming to collect using traditional shipboard techniques. OOS are designed to measure ocean variability at the space-time scales necessary to describe the fundamental physical and biological processes driving the spatial dynamics of coastal marine ecosystems (Schofield et al. 2008). It is therefore not surprising that OOS satellite and HF radar descriptions of mesoscale oceanographic features and processes were useful for modeling the habitats of several ecologically important species in the Mid-Atlantic Bight.

The availability of high resolution, spatially explicit time series data for the Mid-Atlantic Bight allowed us to build models of greater explanatory power than would have been possible using shipboard data alone. We built our GAMs conservatively, constraining the complexity of smoothers, increasing the penalty for model complexity, and considering only habitat features affecting ecological processes. Nevertheless, our models explained 50 to $70 \%$ of the variation in abundance of 4 species with diverse vertical habitat preferences. Furthermore, out-of-sample prediction capabilities of 3 of our 4 models were high. GAM models developed using just shipboard measurements of pelagic and benthic habitat heterogeneity typically explain between 10 to $50 \%$ of abundance variation and generally have poorer out-of-sample prediction capabilities than we measured (e.g. Stoner et al. 2001, 2007, Jensen et al. 2005). Becker et al (2010) also demonstrated that habitat models built with remotely sensed ocean data of the proper resolution have predictive capabilities as good or better than those made with analogous shipboard data alone.

As OOS are designed to sample at the space-time scales necessary to describe the physical and primary production dynamics of the coastal ocean, we were able to consider several fundamental processes controlling ecosystem productivity in our statistical habitat models. Measurements of vertical current velocities, and locations and strengths of fronts were the most valuable of these descriptors of processes known to regulate and structure coastal ocean food webs (Olson et al. 1994, Bakun 2010). Measurements of vertical current velocities allowed us to consider 
A
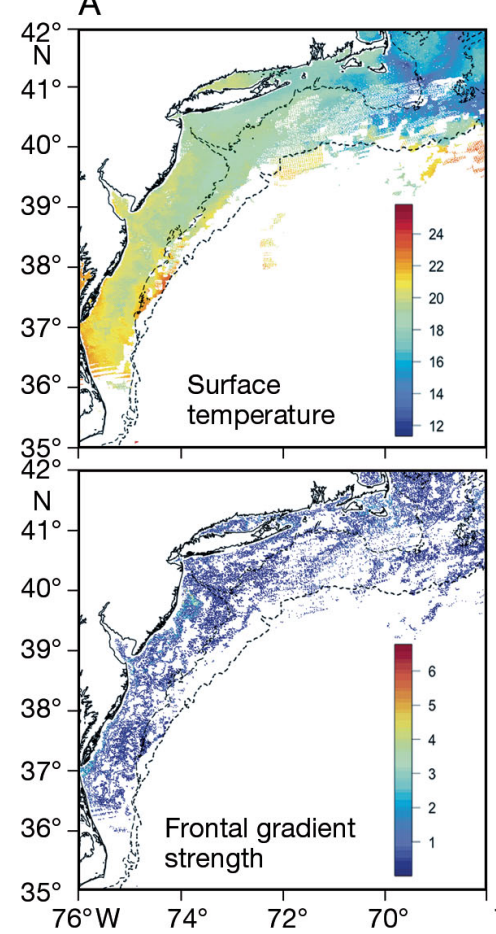
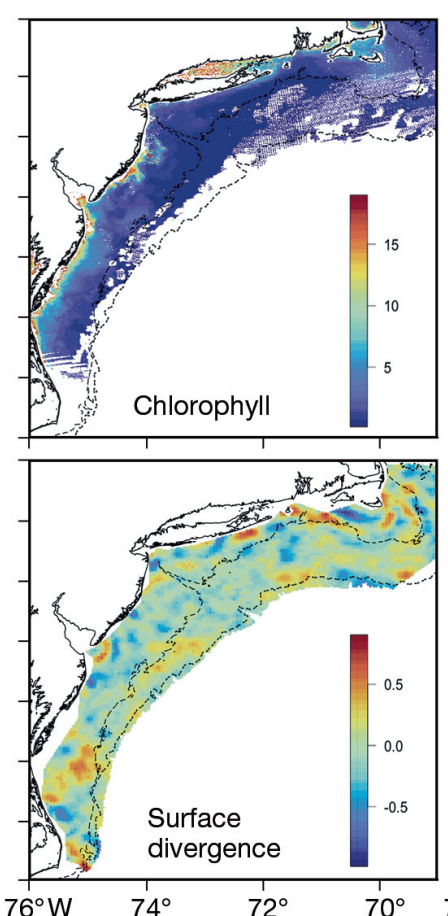

B

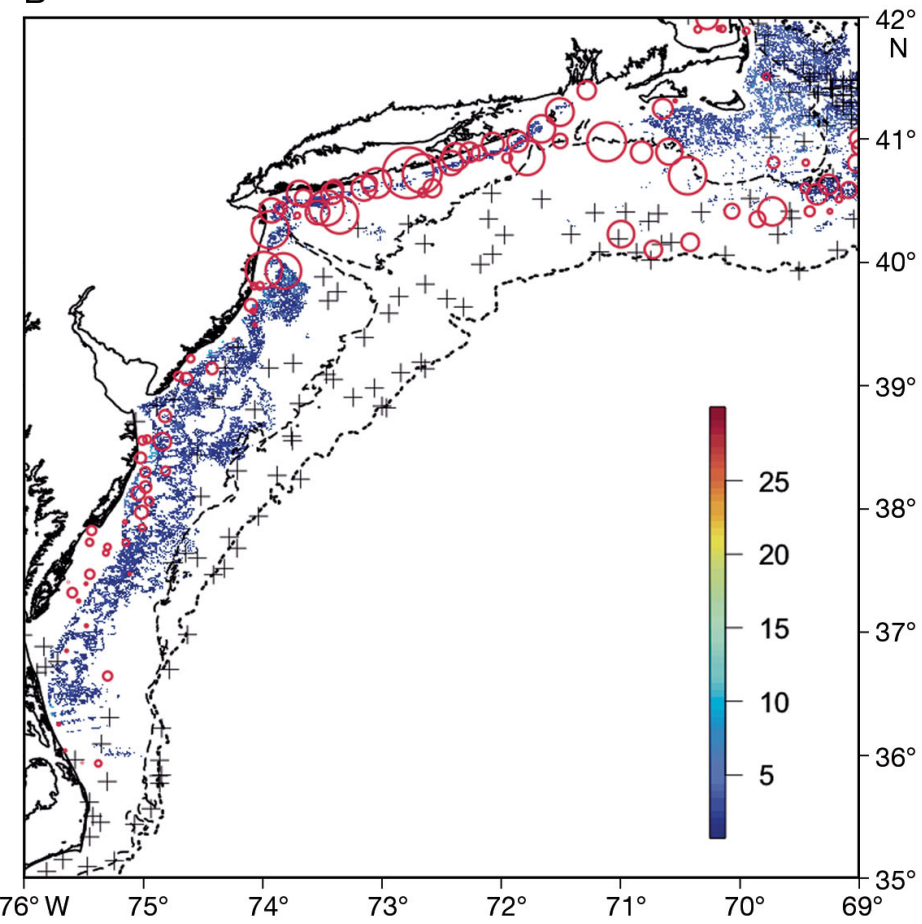

Fig. 3. Pelagic habitat gradients and predicted and realized summer flounder catches during autumn 2008. (A) Pelagic habitat variables ( $8 \mathrm{~d}$ average except for divergence which was $32 \mathrm{~d}$ ) on October 1, 2008 that were used to project a modified generalized additive model (GAM) habitat model for summer flounder. The modified GAM did not include bottom temperature which was too sparsely measured during autumn 2008, and gradient index was replaced with gradient strength to make 'forecasting' tractable. The modified model included log transformed SD of bottom depth as well as the 4 gradients shown in panel A. (B) Summer flounder abundance projected for October 1, 2008 from the modified GAM habitat model in the color gradient. The open red symbols are scaled to the catch of summer flounder per unit effort (CPUE) in Northeast Fisheries Science Centre bottom trawl tows from September through mid-November 2008. + indicates tows in which fish were absent

spatial and temporal variation in upwelling and downwelling potential in our models. Summer flounder were consistently abundant in areas of the coastal ocean where the potential for upwelling was high, while butterfish and squid showed seasonally dependent associations with areas of upwelling. Strong gradients in temperature, salinity, and/or chl $a$ are characteristic of ocean fronts where the interaction of circulation with the buoyancies and behaviors of organisms results in the concentration of food web constituents along them (Helfrich \& Pineda 2003, Genin et al. 2005, Bakun 2010). Our frontal index, which integrated the strength of, and distance to, the nearest frontal gradient met the selection criterion in 3 of our 4 models. The pelagic species, longfin inshore squid and butterfish, were collected near strong surface fronts on the outer continental shelf during winter and early spring. During the same season, summer flounder were more abundant inshore of these strong fronts.

If indices of surface divergence and fronts between water masses referenced physical processes control- ling the spatial structure and dynamics of coastal ocean food, we might have expected species responses to be similar and stronger, and satellite measurements of primary productivity to meet selection criterion in more than one of our GAMs. However, we modeled secondary and tertiary consumers with trophic positions ranging from 3.5 (butterfish) to 4.5 (summer flounder), using only surface habitat features measured directly overhead of trawl samples (Bowman et al. 2000, Hunsicker \& Essington 2006, Smith \& Link 2010). As these animals feed at high trophic levels, they may, under many circumstances, be distributed downstream and later in time than the physics and primary productivity that ultimately supports them (Yamamoto \& Nishizawa 1986, Olson et al. 1994, Bakun 2010). These sorts of space-time lags are highly likely for demersal species like summer flounder and spiny dogfish in deep overwintering habitats that are linked by advection and prey behavior to primary production at the surface along the shelf slope front (Linder et al. 2004, Johnson et al. 2007). Demersal predators at high trophic levels 
Longfin squid $0.77(0.62,0.86)$

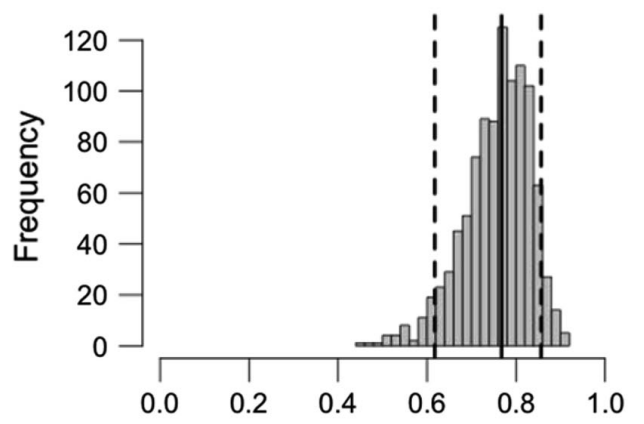

Summer flounder $\mathbf{0 . 6 8}(0.51,0.80)$

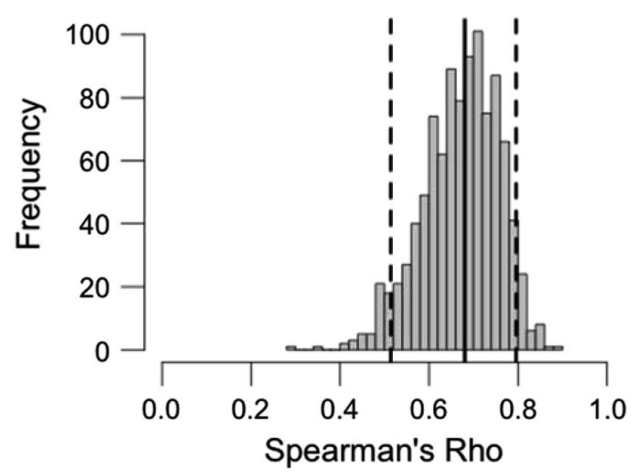

Butterfish 0.53(0.30,0.71)

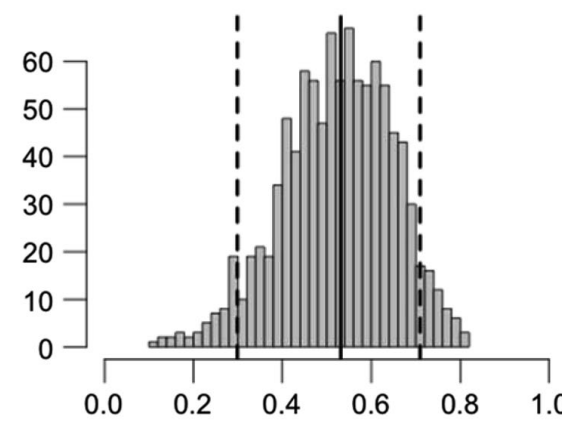

Spiny Dogfish $0.71(0.60,0.81)$

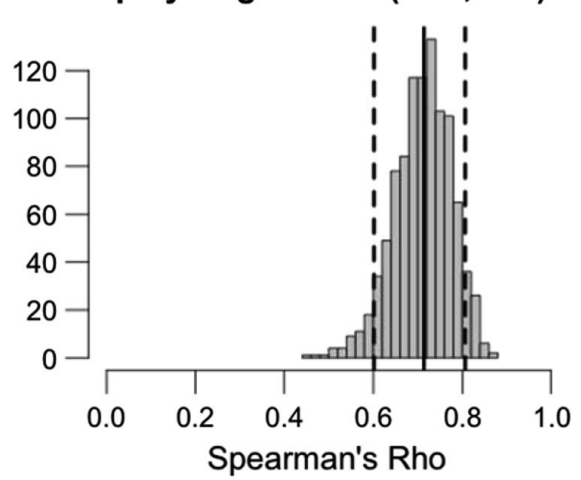

Fig. 4. Bootstrapped (1000 iterations) Spearman correlations (rho) between actual abundances and abundances predicted using habitat covariates in final generalized additive models (GAMs) for each of the 4 species generated with the cross validation out-of-sample prediction procedure (see 'Materials and methods'). Solid lines indicate median correlation while dashed lines are 5th and 95th quantiles for the bootstrapped rho values should be more strongly associated in space and time with the prey they directly consume than with lower trophic levels. We found spiny dogfish and summer flounder to be strongly associated with the squid and butterfish they feed upon during the winter and spring (Torres et al. 2008, Moustahfid et al. 2009, Smith \& Link 2010, Staudinger \& Juanes 2010). In our analyses, the predators were not associated with these prey during autumn. However, during warmer months, including the autumn, spiny dogfish are more abundant north of our study domain, while estuaries are important nurseries and summer feeding habitats for summer flounder that are not sampled in the NEFSC fishery independent bottom trawl surveys (Packer et al. 1999, Stehlik 2009). Thus seasonal changes in the importance of prey in our statistical models for the demersal predators were probably related simultaneously to limitations of the data we analyzed and to seasonal changes in habitat overlap between the specific predators and prey.

Primary productivity as indexed by satellite estimates of chl a only met selection criteria in the model for summer flounder during the autumn migration and spawning period. (Fig. 3, see Supplement). Abundance of the flatfish increased with increases in chl a to a threshold, and the animals were associated with plumes of moderately high chl a occurring outside the mouths of several large MAB estuaries where up- welling potential was also high (Fig. 3). Areas of coastal ocean impacted by estuarine plumes are optically complex, but the high concentrations of colored dissolved organic matter and detritus that confound satellite-based estimates of phytoplankton production also contribute to high productivity (Moline et al. 2008, Pan et al. 2010). The association of summer flounder with estuarine plumes may be purely coincident with migratory pathways between shallow estuarine and coastal feeding habitats and overwintering habitats offshore. However, Berrien \& Sibunka (1999) reported high densities of summer flounder eggs that have stage durations of 48 to $72 \mathrm{~h}$ in these same locations (Johns et al. 1981). We speculate that coastal ocean areas impacted by estuarine plumes where upwelling occurs and productivity is high could serve as high quality spawning grounds that place eggs in close proximity to optimal feeding habitats for larvae which are at a lower trophic level of $\sim 3$ (Grimes \& Kingsford 1996). These same areas also have physical transport mechanisms likely to deliver larvae south and west to important estuarine nurseries (Epifanio \& Garvine 2001, Lentz 2008, Tilburg et al. 2009, Zhang et al. 2009, Gong et al. 2010). Spawning habitat selection and suitability should be largely defined by conditions promoting the development, survival and successful transport of early life stages to juvenile nurseries rather than by the immediate requirements of adults. 
Distributions of the 2 pelagic species were related to horizontal surface currents in our statistical habitat models. During autumn migration, squid and butterfish were more abundant in areas where higher velocity surface flows (and low variance) were directed offshore, while the species were associated with high velocity (low velocity variance) onshore surface flows during the spring. Most swimming and flying animals exploit complex 3-dimensional flows to conserve energy, particularly during long-distance migrations (Liao 2007, Mandel et al. 2008, Mansfield et al. 2009, Stehlik 2009). Associations of the pelagic species with specific surface flows in our models may have reflected the efficient use of cross shelf transport pathways during seasonal migrations. However, the animals were collected in trawls on the bottom where current flows can be different to seasonally complex surface flows (Lentz 2008, Gong et al. 2010). Furthermore, areas with higher velocity, low variance surface flows also tended to have weakly stratified water columns with shallow mixed layers. These are also characteristics of productive habitats (Mann \& Lazier 2006, Bakun 2010). The inverse relationship between horizontal surface currents and water column stratification and stability was largely responsible for the inter-correlated habitat effects and the large amount of deviance explained in our models for pelagic species (Fig. 2). Mechanistic studies are therefore required to determine whether responses of the 2 pelagic species captured by our models reflected preferences for cross shelf transport pathways useful for energy efficient migration, physical conditions promoting high primary productivity, or for areas where both processes occur simultaneously.

The habitat associations of all 4 species, regardless of vertical preference, were better described by the pelagic than the benthic data available to us. Sediment grain sizes estimated at a spatial resolution of $2000 \mathrm{~m}$ did not meet selection criterion in any of our GAMs and species associations with bottom depths and seabed complexity measured at a grain of $93 \mathrm{~m}$ and resolution of $2 \mathrm{~km}$ were seasonally dependent in nearly every case. The interactions between bottom depth and season captured inshore-offshore migrations that were probably more directly related to the seasonal dynamics of temperature and the temperature preferences of the animals than to depth preferences. All of the species except spiny dogfish showed a seasonally independent response to bottom water temperature with a minimum threshold of $\sim 6.5^{\circ} \mathrm{C}$. The animals were concentrated in deep water near the edge of the continental shelf during the winter and early spring when water temperatures are gen- erally warmer and less variable offshore than inshore. Abundance relationships with bottom habitat complexity could have reflected species associations with refuges from predation or current flow if our coarser grained index served as a proxy for bottom complexity at scales of tens of centimeters to tens of meters. However, responses to bottom habitat complexity were also seasonally dependent and complex for 3 of the 4 species, and therefore probably aliased other characteristics of overwintering habitats along submarine valleys and canyons on the outer continental shelf. Animals respond to centimeter to $100 \mathrm{~m}$ scale variability in bottom characteristics, and the data available to us were just too coarse to describe benthic habitat heterogeneity that might have directly affected the survival and energy budgets of the animals (Abookire et al. 2007, Liao 2007, Stoner et al. 2007, Gray \& Elliott 2009). Centimeter to meter scale descriptions of the structural complexity of the seabed have been shown to increase the fit of habitat models (Abookire et al. 2007, Stoner et al. 2007) and the predictive capability of several of our models might have increased if data describing bottom habitat heterogeneity at finer, ecologically relevant scales had been available for our study domain (e.g. Harris \& Stokesbury 2010). Higher resolution bottom data might have improved our model for longfin inshore squid, which deposit egg masses on hard structures located on sand and muddy substrata (Jacobson 2005). However, it is also true that bottom characteristics may be less important to large animals even when they are strongly demersal. Habitat associations of age $1+$ summer flounder on the continental shelf are poorly described by fine scale characteristics of the seabed identified with side scan sonar or underwater video (Lathrop et al. 2006, Slacum et al. 2008). Our results are consistent with speculation that distributions of the flatfish on the continental shelf are determined primarily by mesoscale oceanographic features controlling patterns of productivity and prey distributions rather than by fine-scale seabed characteristics (Slacum et al. 2008).

\section{CONCLUSIONS}

Resource managers are turning increasingly to spatial management as a tool for conserving marine populations and ecosystems (Pérez-Ruzafa et al. 2008, Worm et al. 2009, Edwards \& Plagányi 2011). Regional scale habitat modeling could serve as the foundation for tactical decisions as to where and when to site marine protected and closed areas 
designed to conserve species that provide essential ecosystem services. While much of the seabed remains unmapped, variability in the physical structure, dynamics and productivity of the water column is being measured and mapped at ecologically relevant space/time scales with remote sensing technology integrated into OOS. Furthermore, all OOS are actively developing ensembles of oceanographic models that assimilate data from sensors on satellite, HF radar, underwater robot, and fixed mooring platforms to make spatially and temporally explicit hindcasts and forecasts of the structure and dynamics of the coastal ocean including subsurface features (e.g. Zhang et al. 2010a,b,c). Many of the pelagic features and processes currently measured and modeled by OOS determine patterns of habitat suitability for species and their life stages and could be considered in spatial management (Game et al. 2009, Watson et al. 2011).

In our view, several avenues of research need to be pursued in order to develop habitat models useful for spatial management. These include investigation of the resolution and ranges of habitat variability measured with OOS resulting in biological responses, including the identification of space-time lags between variability in physical and primary production dynamics and responses of important upper level consumers, particularly those associated with the bottom. There is also a need for biological data, in addition to trawl net surveys, to be integrated into OOS (e.g. Kloser et al. 2009, Žydelis et al. 2011). Currently, the data available for broad scale habitat modeling are fisheries-independent surveys designed for stock assessment, not habitat assessment. These surveys are highly selective with respect to season and organism size and often do not sample habitats used during important periods in the life history of many species. Infrequent traditional net surveys cannot be used to distinguish dispersal corridors that many animals move through quickly from areas in which fewer individuals take up longer term residency because habitat resources meet the requirements of particular life history stages. Finally, habitat models based on abundance assume that organisms evaluate habitat quality accurately, without perceptual and movement constraints, and therefore reach abundances at equilibrium with habitat carrying capacity without time delays. This is probably rarely the case, particularly in regions like the Mid-Atlantic Bight where important habitat dimensions are highly dynamic in time and space and many animals are highly migratory. Integration of telemetry and fishery hydroacoustics data into regional OOS (e.g. Kloser et al. 2009, Zydelis et al. 2011) would be useful for addressing some of the sampling biases and assumptions inherent in habitat models based upon traditional fisheries survey data.

We view statistical habitat models informed by OOS, such as those we have developed here, as a first step toward the development of operational mechanistic habitat models: As hypothesis-generating tools that can be coupled with OOS products to perform mechanistic studies of the effects of pelagic, as well as benthic, habitat heterogeneity on the processes of growth, survival, dispersal and reproduction that underlie spatial population dynamics (Kritzer \& Sale 2006, Buckley et al. 2010). This type of adaptive, iterative approach could be a costeffective way to develop mechanistic models with scopes broad enough to meet the requirements of spatial resource management in the sea.

Acknowledgements. We thank S. Lucey, M. Taylor and J. Goff for generously providing us with the data used in our analysis, and S. Gray for his contributions to stimulating discussions about the role of the Integrated Ocean Observing System (IOOS) in fisheries science and management. B. Phelan also provided much needed support. We thank A. Stoner and 3 anonymous reviewers whose comments helped us to improve the manuscript. The NOAA Fisheries and the Environment Program (NA08NMF450626) provided primary support for this research. The authors also thank the following agencies for additional support during this project: NASA Biodiversity NNG06GH75G1/3, NASA New Investigator Program NNH07ZDA001N, NOAA IOOS Office (MARACOOS Grant NA01NOS4730014 and NA07NOS 4730221) and Delaware Sea Grant (NA10OAR4170084).

\section{LITERATURE CITED}

Abookire AA, Duffy-Anderson JT, Jump CM (2007) Habitat associations and diet of young-of-the-year Pacific cod (Gadus macrocephalus) near Kodiak, Alaska. Mar Biol $150: 713-726$

Azarovitz T (1981) A brief historical review of the Woods Hole Laboratory trawl survey time series. In: Doubleday WG, Rivard D (eds) Bottom trawl surveys. Can Spec Publ Fish Aquat Sci 58:62-67

- Bakun A (2010) Linking climate to population variability in marine ecosystems characterized by non-simple dynamics: Conceptual templates and schematic constructs. J Mar Syst 79:361-373

Barrick DE, Evens MW, Weber BL (1977) Ocean surface currents mapped by radar. Science 198:138-144

Beardsley RC, Boicourt WC (1981) On estuarine and continental-shelf circulation in the Middle Atlantic Bight. In: Warren BA, Wunsch C (eds) Evolution of physical oceanography. MIT Press, Boston, p 198-235

Becker EA, Forney KA, Ferguson MC, Foley DG, Smith RC, Barlow J, Redfern JV (2010) Comparing California Current cetacean-habitat models developed using in situ and remotely sensed sea surface temperature data. Mar 
Ecol Prog Ser 413:163-183

Berrien P, Sibunka J (1999) Distribution patterns of fish eggs in the U.S. Northeast Continent Shelf Ecosystem, 19771987. NOAA Tech Rep NMFS 145:310

$>$ Borcard D, Legendre P (1994) Environmental control and spatial structure in ecological communities: an example using oribatid mites (Acari, Orbiatei). Environ Ecol Stat $1: 37-53$

Bowman RE, Stillwell CE, Micheals WL, Grosslein MD (2000) Food of Northeast Atlantic fishes and two common species of squid. NOAA Tech Rep NMFS-F/ME-155

Brodziak JKT, Hendrickson LC (1999) An analysis of environmental effects on survey catches of squids, Loligo pealeii and Illex illecebrosus in the northwest Atlantic. Fish Bull 97:9-24

Buckley LB, Urban MC, Angilletta MJ, Crozier LG, Rissler LJ, Sears MW (2010) Can mechanism inform species' distribution models? Ecol Lett 13:1041-1054

Castelao R, Glenn S, Schofield O, Chant R, Wilkin J, Kohut J (2008) Seasonal evolution of hydrographic fields in the central Middle Atlantic Bight from glider observations. Geophys Res Lett 35; L03617 doi:10.1029/2007GL032335

Ciannelli L, Dingsør GE, Bogstad B, Ottersen G and others (2007) Spatial anatomy of species survival: effects of predation and climate driven environmental variability. Ecology 88:635-646

Collette BG, Klein-MacPhee G (2002) Bigelow and Schroeder's fishes of the Gulf of Maine, xxi. Smithsonian Institution Press, Washington, DC

Cushman SA, McGarigal K (2002) Hierarchical, multi-scale decomposition of species-environment relationships. Landsc Ecol 17:637-646

- Edwards CTT, Plagányi ÉE (2011) Protecting old fish through spatial management: is there a benefit for sustainable exploitation? J Appl Ecol 48:853-863

- Epifanio CE, Garvine RW (2001) Larval transport on the Atlantic continental shelf of North America: a review. Estuar Coast Shelf Sci 52:51-77

Ficetola GF, Denoël M (2009) Ecological thresholds: an assessment of methods to identify abrupt changes in species habitat relationships. Ecography 32:1075-1084

Game ET, Grantham HS, Hobday AJ, Pressey RL and others (2009) Pelagic protected areas: the missing dimension in ocean conservation. Trends Ecol Evol 24:360-369

Genin A, Jaffe JS, Reef R, Richter C, Franks PJS (2005) Swimming against the flow: a mechanism of zooplankton aggregation. Science 308:860-862

> Goff JA, Jenkins C, Calder B (2006) Maximum a posteriori resampling of noisy, spatially correlated data. Geochem Geophys Geosys 7, Q08003 doi:10.1029/2006GC001297

> Goff JA, Jenkins CJ, Williams SJ (2008) Seabed mapping and characterization of sediment variability using the usSEABED data base. Cont Shelf Res 28:614-633

Gong D, Kohut JT, Glenn SM (2010) Seasonal climatology of wind-driven circulation on the New Jersey Shelf. J Geophys Res 115:C04006 doi:10.1029/JC005520

Gray JS, Elliott M (2009) Ecology of marine sediments. Oxford University Press, Oxford

Grimes C, Kingsford M (1996) How do riverine plumes of different sizes influence fish larvae: Do they enhance recruitment? Mar Freshw Res 47:191-208

Harris BP, Stokesbury KDE (2010) The spatial structure of local surficial sediment characteristics on Georges Bank, USA. Cont Shelf Res 30:1840-1853

Hatfield EMC, Cadrin SX (2002) Geographic and temporal patterns in size and maturity of the longfin inshore squid (Loligo pealeii) off the northeastern United States. Fish Bull 100:200-213

> Helfrich KR, Pineda J (2003) Accumulation of particles in propagating fronts. Limnol Oceanogr 48:1509-1520

Hsieh CH, Yamauchi A, Nakazawa T, Wang WF (2010) Fishing effects on age and spatial structures undermine population stability of fishes. Aquat Sci 72:165-178

Hunsicker ME, Essington TE (2006) Size-structured patterns of piscivory of the longfin inshore squid (Loligo pealeii) in the mid-Atlantic continental shelf ecosystem. Can J Fish Aquat Sci 63:754-765

Jacobson LD (2005) Essential fish habitat source document: Longfin inshore squid, Loligo pealeii, life history and habitat characteristics. NOAA Tech Memo NMFS-NE-193

Jensen OP, Seppelt R, Miller TJ, Bauer LJ (2005) Winter distribution of blue crab Callinectes sapidus in Chesapeake Bay: application and cross-validation of a two-stage generalized additive model. Mar Ecol Prog Ser 299:239-255

> Johns DM, Howell WH, Klein-MacPhee G (1981) Yolk utilization and growth to yolk-sac absorption in summer flounder (Paralichthys dentatus) larvae at constant and cyclic temperatures. Mar Biol 63:301-308

Johnson NA, Campbell JW, Moore TS, Rex MA, Etter RJ, McClain CR, Dowell MD (2007) The relationship between the standing stock of deep-sea macrobenthos and surface production in the western North Atlantic. DeepSea Res I 54:1350-1360

Kerr LA, Cadrin SX, Secor DH (2010) The role of spatial dynamics in the stability, resilience, and productivity of an estuarine fish population. Ecol Appl 20:497-507

$>$ Kloser RJ, Ryan TE, Young JW, Lewis ME (2009) Acoustic observations of micronekton fish on the scale of an ocean basin: potential and challenges. ICES J Mar Sci 66: 998-1006

Kritzer JP, Sale PF (2006) Marine metapopulations. Academic Press, Amsterdam

> Lathrop RG, Cole M, Senyk N, Butman B (2006) Seafloor habitat mapping of the New York Bight incorporating sidescan sonar data. Estuar Coast Shelf Sci 68:221-230

> Lentz SJ (2008) Observations and a model of mean circulation over the Middle Atlantic Bight continental shelf. J Phys Oceanogr 38:1203-1220

Levitus S (1982) Climatological atlas of the world's oceans. NOAA Professional Paper 13:173

Liao JC (2007) A review of fish swimming mechanics and behaviour in altered flows. Philos Trans R Soc B 362: 1973-1993

Linder CA, Gawarkiewicz GG, Pickart RS (2004) Seasonal characteristics of bottom boundary layer detachment at the shelfbreak front in the Middle Atlantic Bight. J Geophys Res 109:C03049 doi:10.1029/U2003JC002032

> Link J, Overholtz W, O'Reilly J, Green J and others (2008) The Northeast U.S. continental shelf Energy Modeling and Analysis exercise (EMAX): ecological network model development and basic ecosystem metrics. J Mar Syst 74:453-474

> Mandel JT, Bildstein KL, Bohrer G, Winkler DW (2008) Movement ecology of migration in turkey vultures. Proc Natl Acad Sci USA 105:19102-19107

Mann K, Lazier J (2006) Dynamics of marine ecosystems: biological-physical interactions in the oceans, 3rd edn. Blackwell Publishing, Oxford

Mansfield K, Saba V, Keinath J, Musick J (2009) Satellite tracking reveals a dichotomy in migration strategies 
among juvenile loggerhead turtles in the Northwest Atlantic. Mar Biol 156:2555-2570

Marra J, Houghton RW, Garside C (1990) Phytoplankton growth at the shelf-break front in the Middle Atlantic Bight. J Mar Res 48:851-868

Moline MA, Frazer TK, Chant R, Glenn S and others (2008) Biological responses in a dynamic buoyant river plume. Oceanography 21:70-89

Mora C, Metzger R, Rollo A, Myers RA (2007) Experimental simulations about the effects of overexploitation and habitat fragmentation on populations facing environmental warming. Proc R Soc B 274:1023-1028

> Moustahfid H, Tyrrell MC, Link JS (2009) Accounting explicitly for predation mortality in surplus production models: an application to longfin inshore squid. North Am J Fish Manage 29:1555-1566

Moustahfid H, Tyrrell MC, Link JS, Nye JA, Smith BE, Gamble RJ (2010) Functional feeding responses of piscivorous fishes from the northeast US continental shelf. Oecologia. 163:1059-1067

Mugo R, Saitoh SI, Nihira A, Kuroyama T (2010) Habitat characteristics of skipjack tuna (Katsuwonus pelamis) in the western North Pacific: a remote sensing perspective. Fish Oceanogr 19:382-396

Neteler M, Mitasova H (2008) Open source GIS: A GRASS GIS approach. Springer, New York, NY

> Oliver MJ, Irwin AJ (2008) Objective global ocean biogeographic provinces. Geophys Res Lett 35:L15601 doi: 10.1029/2008GL034238

Oliver MJ, Glenn SM, Kohut JT, Irwin AJ, Schofield OM, Moline MA, Bissett WP (2004) Bioinformatic approaches for objective detection of water masses on continental shelves. J Geophys Res 109:C07S04 doi:10.1029/2003JC 002072

Olson DB, Hitchcock GL, Mariano AJ, Ashjian CJ, Peng G, Nero RW, Podestá GP (1994) Life on the edge: marine life and fronts. Oceanography 7:52-60

Packer DB, Hoff T (1999) Life history, habitat parameters, and essential habitat of Mid-Atlantic summer flounder. Am Fish Soc Symp 22:76-92

Packer DB, Griesbach S, Berrien PL, Zetlin C, Johnson DL, Morse WW (1999) Essential fish habitat source document: summer flounder, Paralichthys dentatus, life history and habitat characteristics. NOAA Tech Memo NMFS-NE-151

> Pan X, Mannino A, Russ ME, Hooker SB, Harding LW Jr (2010) Remote sensing of phytoplankton pigment distribution in the United States northeast coast. Remote Sens Environ 114:2403-2416

Pérez-Ruzafa A, Martín E, Marcos C, Miguel Zamarro J and others (2008) Modeling spatial and temporal scales for spill-over and biomass exportation from MPAs and their potential for fisheries enhancement. J Nat Conserv 16: 234-255

> Pearce J, Ferrier S (2000) An evaluation of alternative algorithms for fitting species distribution models using logistic regression. Ecol Model 128:127-147

Reid JM, Reid JA, Jenkins CJ, Hastings ME, Williams SJ, Poppe LJ (2005) usSEABED: Atlantic coast offshore surficial sediment data release: U.S. Geological Survey Data Series 118, version 1.0. Online at http://pubs.usgs.gov/ ds/2005/118/

Ryan JP, Yoder JA, Cornillon PC (1999) Enhanced chlorophyll at the shelfbreak of the Mid-Atlantic Bight and Georges Bank during the spring transition. Limnol
Oceanogr 44:1-11

Schofield O, Chant RB, Cahill RC, Gong D and others (2008) The decadal view of the Mid-Atlantic Bight from the COOLroom: Is our coastal system changing? Oceanography 21:108-117

Secor DH, Kerr LA, Cadrin SX (2009) Connectivity effects on productivity, stability, and persistence in a herring metapopulation model. ICES J Mar Sci 66:1726-1732

Simpson JH (1981) The shelf fronts: implications of their existence and behaviour. Philos Trans R Soc A 302: $531-546$

> Simpson JH, Bowers D (1981) Models of stratification and frontal movement in shelf seas. Deep-Sea Res A 28: $727-738$

Slacum HW, Istad JH, Weber ED, Richkus WA, Diaz RJ, Tallent CO (2008) The value of applying commercial fishers experience to designed surveys for identifying characteristics of essential fish habitat for adult summer flounder. North Am J Fish Manage 28:710-721

Smith B, Link J (2010) The trophic dynamics of 50 finfish and 2 squid species on the Northeast US continental shelf. NOAA Tech Memo NMFS-NE-216

Staudinger MD (2006) Seasonal and size-based predation on two species of squid by four fish predators on the Northwest Atlantic continental shelf. Fish Bull 104: 605-615

Staudinger MD, Juanes F (2010) A size-based approach to quantifying predation on longfin inshore squid Loligo pealeii in the northwest Atlantic. Mar Ecol Prog Ser 399: 225-241

Stehlik LL (2007) Essential fish habitat source document: Spiny dogfish, Squalus acanthias, life history and habitat characteristics, 2nd edn. NOAA Tech Mem NMFS-NE203

Stehlik LL (2009) Effects of seasonal change on activity rhythms and swimming behavior of age-0 bluefish (Pomatomus saltatrix) and a description of gliding behavior. Fish Bull 107:1-12

Stoner AW, Manderson JP, Pessutti J (2001) Spatiallyexplicit analysis of estuarine habitat for juvenile winter flounder (Pseudopleuronectes americanus): combining generalized additive models and geographic information systems. Mar Ecol Prog Ser 213:253-271

Stoner AW, Spencer ML, Ryer CH (2007) Flatfish-habitat associations in Alaska nursery grounds: use of continuous video records for multi-scale spatial analysis. J Sea Res 57:137-150

> Tian RC, Chen C, Stokesbury KDE, Rothschild B and others (2009) Modeling the connectivity between sea scallop populations in the Middle Atlantic Bight and over Georges Bank. Mar Ecol Prog Ser 380:147-160

Tilburg CE, Dittel AI, Epifanio CE (2009) High concentrations of blue crab (Callinectes sapidus) larvae along the offshore edge of a coastal current: effects of convergent circulation. Fish Oceanogr 18:135-146

> Torres LG, Read AJ, Halpin P (2008) Fine-scale habitat modeling of a top marine predator: Do prey data improve predictive capacity? Ecol Appl 18:1702-1717

Valavanis V, Pierce G, Zuur A, Palialexis A, Saveliev A, Katara I, Wang J (2008) Modeling of essential fish habitat based on remote sensing, spatial analysis and GIS. Hydrobiologia 612:5-20

> Watson JR, Hays CG, Raimondi PT, Mitarai S and others (2011) Currents connecting communities: nearshore community similarity and ocean circulation. Ecology 92: 
1193-1200

Wood S (2006) Generalized Additive Models: an introduction with R. Chapman \& Hall, Boca Raton, FL

Worm B, Hilborn R, Baum JK, Branch TA and others (2009) Rebuilding global fisheries. Science 325:578-585

Yamamoto T, Nishizawa S (1986) Small-scale zooplankton aggregations at the front of a Kuroshio warm-core ring. Deep-Sea Res A 33:1729-1740

Zainuddin M, Katsuya S, Saitoh SI (2008) Albacore (Thunnus alalunga) fishing ground in relation to oceanographic conditions in the western North Pacific Ocean using remotely sensed satellite data. Fish Oceanogr 17: 61-73

Zhang W, Wilkin JL, Chant RJ (2009) Modeling the pathways and mean dynamics of river plume dispersal in the New York Bight. J Phys Oceanogr 39:1167-1183

Editorial responsibility: Kenneth Sherman,

Narragansett, Rhode Island, USA
Zhang WG, Wilkin JL, Arango HG (2010a) Towards an integrated observation and modeling system in the New York Bight using variational methods. Part I: 4DVAR data assimilation. Ocean Model 35:119-133

Zhang WG, Wilkin JL, Levin JC (2010b) Towards an integrated observation and modeling system in the New York Bight using variational methods. Part II: Repressenter-based observing strategy evaluation. Ocean Model 35:134-145

Zhang WG, Wilkin JL, Schofield OM (2010c) Simulation of water age and residence time in New York Bight. J Phys Oceanogr 40:965-982

Žydelis R, Lewison, RL, Shaffer SA, Moore JE and others (2011) Dynamic habitat models: using telemetry data to project fisheries bycatch. Proc R Soc B doi:10.1098/ rspb.2011.0330

Submitted: January 17, 2011; Accepted: July 19, 2011

Proofs received from author(s): September 15, 2011 